\title{
Greenways for recreation and maintenance of landscape quality: five case studies in Portugal
}

\author{
Luís Ribeiro $^{\mathrm{a}, *}$, Teresa Barão ${ }^{\mathrm{b}}$ \\ ${ }^{a}$ Lisbon Technical University, High Institute of Agronomy, Lisbon 1300, Portugal \\ ${ }^{\mathrm{b}}$ Topiaris Lda., Portugal
}

Available online 15 January 2005

\begin{abstract}
The use of the concept of greenway can be identified in Portugal throughout the 20th century as a planning and design tool. Several examples, such as the 'Improvement Plans for Lisbon' by Ressano Garcia (1901), the continuum naturale concept [Cabral, F.C., 1980. O Continuum Naturale e a Conservação da Natureza. Conservação da Natureza. Serviço de Estudos do Ambiente, Lisbon; Andresen, T., 2001. Francisco Caldeira Cabral. Landscape Design Trust, Surrey, UK, 213 pp.], the Green Plan for Lisbon [Telles, G.R., et al., 1997. Plano Verde de Lisboa. Ed. Colibri, Lisboa, 197 pp.], deal with the subjects of implementing vegetation corridors, pedestrian networks and landscape quality. These examples establish Portuguese planning and design tradition within the international greenway movement first identified by Fabos [Fabos, J.Gy., 1991. From Park to Greenways into the 21st Century. In: Proceedings from Selected Educational Sessions, ASLA Annual Meeting, Kansas City, Missouri]. Though several projects have been developed at the planning level, there is a need to analyze the applicability of such a concept at the regional, municipal and local level. We must consider the characteristics of Portugal's cultural landscape, recognition by other professions dealing with planning and involvement by politicians. By analyzing five case studies, this paper shows the significance of the greenway as a planning and design strategy, which coincides, with the current objectives of political and planning authorities at the municipal level. It also proves that it is possible to reconcile political objectives and urban development while safeguarding landscape quality and providing new opportunities for public recreation and education. Greenway planning and design is now undoubtedly a subject of growing significance in Portugal.
\end{abstract}

(C) 2004 Elsevier B.V. All rights reserved.

Keywords: Greenway planning; Greenway design; Landscape assessment; Landscape conservation; Portugal

\section{Introduction}

Greenway planning has been identified as an international movement, which emerged from the practice

\footnotetext{
* Corresponding author.

E-mail addresses: 1.ribeiro@mail.pt (L. Ribeiro), teresa.barao@net.novis.pt (T. Barão).
}

and theory of landscape architects, developed throughout the 19th and 20th centuries (Fabos, 1995). The growing success of the greenway concept can be related to its effectiveness in achieving its aims to foster landscape conservation, protect heritage and provide opportunities for public recreation. For the purpose of this paper, landscape conservation should be understood as a group of strategies aimed at safeguarding 
natural and cultural resources, as well as rehabilitating and improving derelict land in rural and urban contexts.

In Portugal, the greenway concept has evolved from its roots in the late 19 th century when it dealt with strategies for beautifying city roads. It has now become a significant tool for implementing urban and regional planning practices. The greenway has been a success not only due to its evolution and ability to adapt to different natural, cultural and historic contexts. But also, it is capable of creating consensus between different professional backgrounds via the common goal to conserve and improve landscape quality.

This paper has two main objectives. First, it intends to prove that the greenway is an international movement which has been present and used by planners in Portugal and which government institutions are coming to understand is increasingly significant due to increasing public demand for implementing greenways. This is shown through an analysis of the evolution of landscape architecture and planning practices in this country.

The second objective aims to show, through the analysis of five case studies, the significance of the greenway movement in the current context of urban and regional planning, its applicability to very diverse landscapes and the role of landscape architects in the planning and design phases. The five case studies - the Sintra Greenway of Outstanding Landscape Quality, the Greenway of Vila-Franca-de-Xira Hills, the Urban Greenway of Tomar, the Greenway of Alpiarça Canal, and the Urban Greenway of Alenquer River were selected from among several studies, plans and projects related to greenway on which the authors have collaborated between 1997 and 2002. They are located in the center of the country along the Tagus Valley and its tributaries. These examples represent different scales of approach - from regional to local - and different objectives - resource protection, urban beautification and leisure and development opportunities. They always share a common goal however, to conserve and improve the quality of the landscape.

\section{Evolution of the greenway concept in Portugal}

The greenway concept can be easily identified in Portugal throughout the 20th century as a planning and design tool. However, some of the first Portuguese attempts at landscape planning demonstrate a certain awareness concerning the protection of resources based upon linear territorial patterns. This is the case of the Douro Wine Region, which was established by Marquês de Pombal, the same Prime Minister who reconstructed Lisbon after the 1775 earthquake. The aim of delineating the Douro Region was to protect and foster the production of Douro wine in the sunny and dry hills along the Douro River. In turn, it established the basis for the development of a cultural landscape, which was classified as a World Heritage Landscape in 2001.

But different plans developed for the city of Lisbon and region since the beginning of the 20th century are major evidence of the use of linear structures along the land in order to improve the landscape with the purpose of landscape qualification. The Lisbon Plan for Improvements by the engineer Ressano Garcia (1847-1911) was developed to accommodate Lisbon's expansion, between 1878 and 1900, when the population increased by $56 \%$ (Marques, 1981). The plan, approved in 1904, became the first planned continuous system of public parks, public gardens and boulevards. But the first comprehensive planning approach to Lisbon appeared in 1927 with Forrestier's plan. This plan advocated the need for a park system plan that would guide urban expansion and employed the garden city concept (Lôbo, 1995).

After the 1930s, with growing state intervention, several plans were developed which show greater concern for protecting the landscape. Two of these plans are worth mentioning. In the first, De Gröer's Plan (De Gröer, 1948) proposed a rural belt of protection to control Lisbon's urban expansion. The projected system also included a highway network buffered by green areas, clearly inspired by the American Parkways as well as public gardens and parks. This plan shows an evolution towards the use of linear structures for the landscape on a larger scale. This trend was taken further by the Lisbon Regional Master Plan, which the Ministry for Public Works developed and completed in 1964. The regional approach also included delineation of protective corridors in an attempt to control urban growth. Delays in approving this plan made necessary its revision in 1973. This plan included the definition of a comprehensive approach to landscape conservation. It also showed concern for protecting resources by 
implementing continuous areas of valuable resources, such as linking the Jamor Valley to Monsanto Park, the largest green area defined in previous municipal plans.

But it was the development of two legal planning instruments after 1974 which fostered the creation of green structures a regional scale: the National Agriculture Reserve (Reserva Agrícola Nacional, RAN, law 451/82) and the National Ecological Reserve (Reserva Ecológica Nacional, REN, law 3212/83). Caldeira Cabral (1908-1992) (Cabral, 1980) - who started landscape architecture education in Portugal during the 1940s - first proposed the concept underlying RAN and REN with the designation of continuum naturale, a way of linking green urban systems with the surrounding rural landscape, such as he proposed for the City of Lisbon (Andresen, 2001).

The National Agricultural Reserve and the National Ecological Reserve became significant instruments for protecting landscape quality by focusing on areas where most of the valuable and fragile resources are located. Though the RAN (National Agricultural Reserve) and the REN (National Ecological Reserve) are based on natural characteristics of the land - water lines, flood plains, areas of high infiltration rate and slope, and good soils - it has been shown that these areas are also extremely significant for their cultural and historical resources (Ribeiro, 1998), as well as for recreation opportunities and to delineate an urban park system in Lisbon (Telles, 1992). This co-occurrence corroborates international landscape research in different geographic contexts such as in New England (Ahern, 1995) and Georgia in the US (Dawson, 1995). More recently several studies developed for the Lisbon Metropolitan Area also show the importance of spatial distribution of resources in defining a network of greenways for the Lisbon Metropolitan Area (Machado et al., 1995; Ribeiro, 1998).

The current planning and design context is very much influenced by the significance the European Union has been giving to plans and projects related to the environment and improving quality of life. In Portugal, different governmental programs have allocated these funds. Among these, the Polis program is worth mentioning since it promotes the development of plans and design projects geared towards the urban and environmental improvement of cities. In the first phase 28 cities were chosen, enabling multidisciplinary teams to develop projects (ProgramaPolis, 2002). An
Table 1

The significance and magnitude of the Polis program in Portugal (ProgramaPolis, 2002)

\begin{tabular}{ll}
\hline Types interventions & Numbers \\
\hline Parks and green areas & $5935 \mathrm{~km}^{2}$ \\
Improvement of public spaces & $1852 \mathrm{~km}^{2}$ \\
Improvement of river fronts & $737 \mathrm{~km}$ \\
Improvement of sea fronts & $159 \mathrm{~km}$ \\
Biking trails & $1031 \mathrm{~km}$ \\
New pedestrian ways & $1359 \mathrm{~km}$ \\
\hline
\end{tabular}

analysis of the type of interventions as well as its extension shows a significant emphasis on linear outdoor projects (Table 1). Out of the 28 selected cities, 18 have projects related to water and riverfronts.

The examples mentioned above such as the continuum naturale concept (Cabral, 1980) and the Green Plan for Lisbon (Telles et al., 1997), recognize the valuable role of spatial patterns of landscape resources in the planning and design of greenway networks. These examples establish Portuguese planning and design tradition within the international greenway movement first identified by Fabos (1991).

\section{Methods for greenway planning}

The thesis that the most valuable landscape resources - areas of ecological and natural significance, cultural and historic values, and recreational opportunities - tend to co-occur in common spatial distribution patterns in the landscape has been the main supporting thesis of greenway planning (Lewis, 1964; Fabos, 1991; Dawson, 1995; Ribeiro, 1998).

According to Fabos, ". . the most significant recreation, historic/cultural, and ecological resources [cooccur] within our natural river, and coastal regions" (1991, p. 12). Lewis (1964) at the University of Wisconsin first drew attention to the importance of cooccurrence of landscape resources in the delineation of environmental corridors. His proposal for Wisconsin Heritage Trails proved that cultural, and historical resources followed patterns of distribution in the landscape in concurrence with natural/ecological corridors, and recreation opportunities. Considering 220 different natural and cultural factors in Wisconsin, Lewis found that they co-occur along corridors, which he named environmental corridors (Lewis, 1964, p. 106). Dawson 
(1995, p. 28) also showed that in the State of Georgia, the most valuable landscape resources tend to be concentrated along rivers, ridges, steep slopes, coastal areas, defining corridor-like areas of concentrated environmental value.

Since greenway planning has been linked to the identification and assessment of areas with special resource value, most of the time the methods used are based on parametric approaches to landscape analysis and assessment, commonly used in landscape architecture. Methods for landscape assessment evolved from the work of pioneers in landscape planning such as Geddes's regional survey (1915, p. 364-365) and Henry Wright's use of map overlays (Churchill, 1983, p. 211), to more sophisticated methods which enable an organized systematic and logical sequence supporting landscape planning. These methods deal with natural and cultural characteristics of the land such as the parametric approach first systematized by McHarg (1968, p. 87), or the METLAND planning model (Fabos and Caswell, 1977, p. 15). All of these methods include phases of landscape analysis, landscape assessment, planning proposals and evaluation.

Landscape architecture delineates corridors using the distribution patterns of the most significant areas shown by assessment. Currently, the greenway movement builds on scientific theories and principles such as the meta-population and island bio-geographic theories of ecology (Ahern, 1995), which justify the need for ecological connectivity. To implement continuity in areas of value, greenway planning is increasingly using Gap analysis (Machado et al., 1995). Gap analysis is a method developed for wildlife management but which has supported landscape planning decisions in order to protect areas important for their landscape value or because they can provide significant opportunities for improving continuity through valuable areas.

How patterns of resource distribution are used may be explained in many different ways. Several planning and design strategies have been used to delineate greenways. Ahern has systematized some of these strategies as protective, defensive, offensive and opportunistic (Ahern, 1995, p. 140).

Critics of rational planning - aimed at the "rational, and deterministic" sequence of research-analysisassessment-evaluation - have argued that the process does not sufficiently explain the planning and design processes nor support a comprehensive theoretical framework. Landscape planners often attempt to fit their plans into landscape patterns, since the success of their proposals is dependent upon this method. But this is not to say that the understanding and assessment of the natural patterns will be sufficient to achieve a plan or a design solution, since different plans can be designed for the same region (Lyle, 1985, p. 127). The greenway planning approach addresses the role of creativity, without refusing scientific theories, principles and methodologies of landscape planning. Linearity and connectivity have undoubtedly been used as means to address formal, metaphorical and aesthetic issues in landscape design.

Within these perspectives, greenway planning can be seen as an innovative concept that attempts to address post-modern criticism, which has evolved simultaneously in the field of landscape architecture. These multiple characteristics of being creative, building on traditional methods of landscape assessment, and considering multiple public values and initiative, makes the greenway approach appear to be an appropriate reaction and answer to post-modern criticism in the area of landscape planning.

The following five case studies are intended to show the suitability of landscape assessment as a crucial step in the approach to greenway planning and design, as well as the applicability of the greenway concept for conserving and improving the Portuguese landscape. Presentation and analyses of these five greenways - the Sintra Greenway of Outstanding Landscape Quality, the Greenway of Vila-Franca-de-Xira Hills, the Urban Greenway of Tomar, the Greenway of Alpiarça Canal, and the Urban Greenway of Alenquer River - begin with a case approached from the regional planning level and a larger scale, and moves towards examples of a more local scale in which the design approach becomes increasingly more significant.

\section{Five Portuguese greenways}

\subsection{The Sintra Greenway: a network of Outstanding Landscape Quality}

\subsubsection{General context and objectives}

The Sintra Greenway of Outstanding Landscape Quality was proposed within the scope of the environmental and landscape section of the Sintra Strategic 
Plan, developed in 1998, under the coordination of the CEDRU planning office (Centro de Estudos de Desenvolvimento Regional e Urbano) (Simões et al., 1995). This plan established the bases for revising an existing land use plan and involved a diversified team of geographers, architects, landscape architects, traffic engineers, historians, tourism planners, and infrastructure engineers.

Sintra is a municipality in the Lisbon Metropolitan Area with an area of approximately $400 \mathrm{~km}^{2}$. The territory includes outstanding heritage in terms of diversity and quality making it a unique landscape within the national and international context. UNESCO has recognized this value internationally through its classification as a World Heritage Landscape.

In addition to its rich landscape, the Sintra municipality has also had to deal with significant problems related to urban expansion. Areas of lesser quality almost isolate Sintra's unique resources into clusters of exceptional quality. The proposed concept to protect and improve the quality of the landscape as well as of the environment in general was supported by the greenway concept. A network of areas which still include valuable resources delineated as Corridors of Outstanding
Landscape Quality was proposed as a strategy to conserve existing quality and project it into new areas of development.

\subsubsection{Landscape assessment and identification of valuable resources}

The methodology used to delineate this network included steps which landscape planning currently employs, namely: analysis, assessment and identification of valuable resources. These steps were followed by an analysis of the distribution patterns and the delineation of homogeneous areas of landscape. The procedure is represented in Fig. 1.

Landscape analysis includes natural and cultural factors such as geomorphology, physiography, natural drainage network, land use, historic/cultural sites. These factors were used to identify the most valuable resources within the Sintra landscape. Natural resources were assessed in terms of biodiversity, ecological functions, water and soil conservation and natural history potential for interpretation and research. The assessment revealed several linear patterns of concentration along natural features (Fig. 2) such as the Sintra range, the Atlantic coast, the natural drainage network,

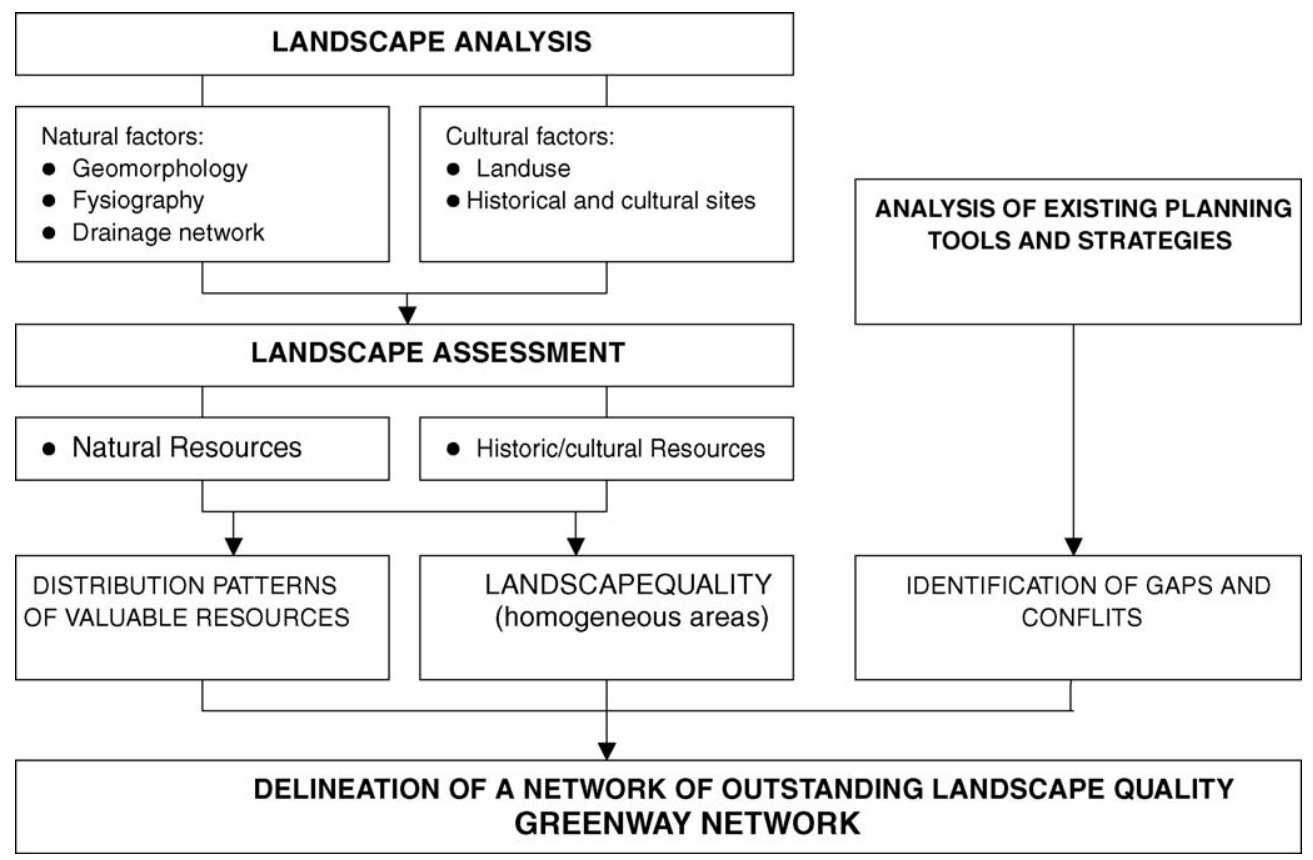

Fig. 1. Methodology for greenway planning in Sintra municipality. 


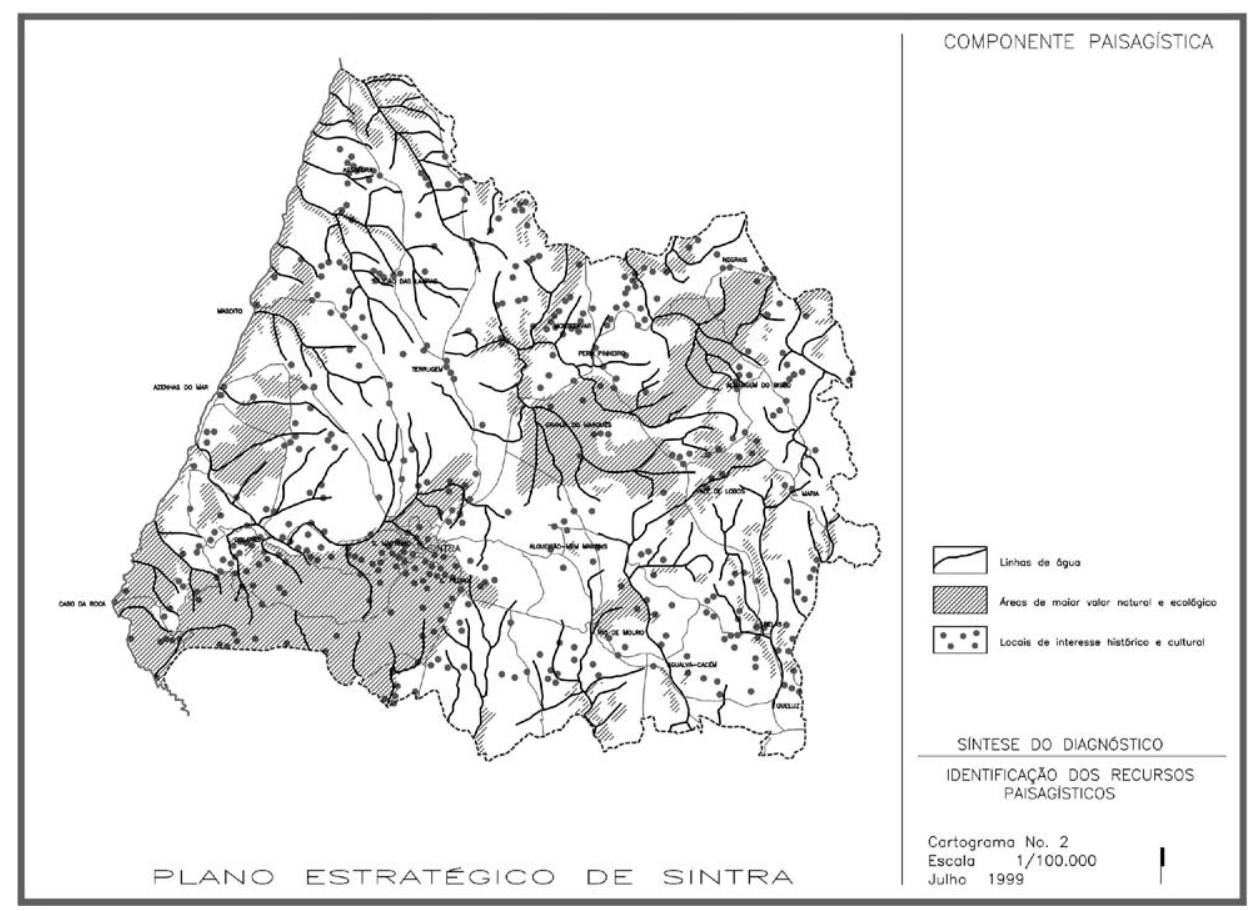

Fig. 2. Spatial distribution patterns of valuable resources in Sintra municipality.

and the valleys. The granite range that runs from West to East determines Sintra's physiography. This range reaches $528 \mathrm{~m}$ high, contrasting with a platform of sedimentary formations that develops in the north, settled with little rural villages spread throughout an agricultural area. Deep and narrow valleys from east to west towards the Atlantic coast cut this sedimentary platform. High and steep cliffs allowing for the existence of small beaches characterize the coast. These geomorphologic features concentrate the most valuable natural resources.

Sintra is a municipality rich in sites and areas in terms of culture and history. A survey carried out in 1998 identified about 500 sites, the most frequent and significant belonging to the following classes (Ribeiro, 1998): farm/leisure estates, windmills, rural settlements, castles and military structures, as well as religious buildings. The assessment of cultural/historic resources revealed patterns of concentration along stream corridors and ridgelines (Fig. 2). Specific patterns were identified along hillsides that enable the connection of ridgelines and river systems, mainly including farm/leisure estates (Ribeiro, 1998).
The assessment of valuable natural and cultural/historic resources was used to define homogenous zones of landscape quality. Ten different zones were identified according to the distribution patterns of resources as well as land use (Fig. 3).

\subsubsection{Greenway planning}

The strategy proposed to improve the quality of the landscape based on the following principles and goals:

- The quality and diversity of Sintra's landscape should be considered a valuable and supporting resource for the Lisbon Metropolitan Area to achieve prominence and competitiveness internationally, for recreation of the metropolitan population and for increasing high quality tourism.

- To implement programs to restore and rehabilitate natural and heritage resources which form the bases of the Sintra landscape's specific character.

- Sintra's image related to the character of its cultural landscape should be used as a means to establish the municipality as a cultural center within the metropolitan area. 


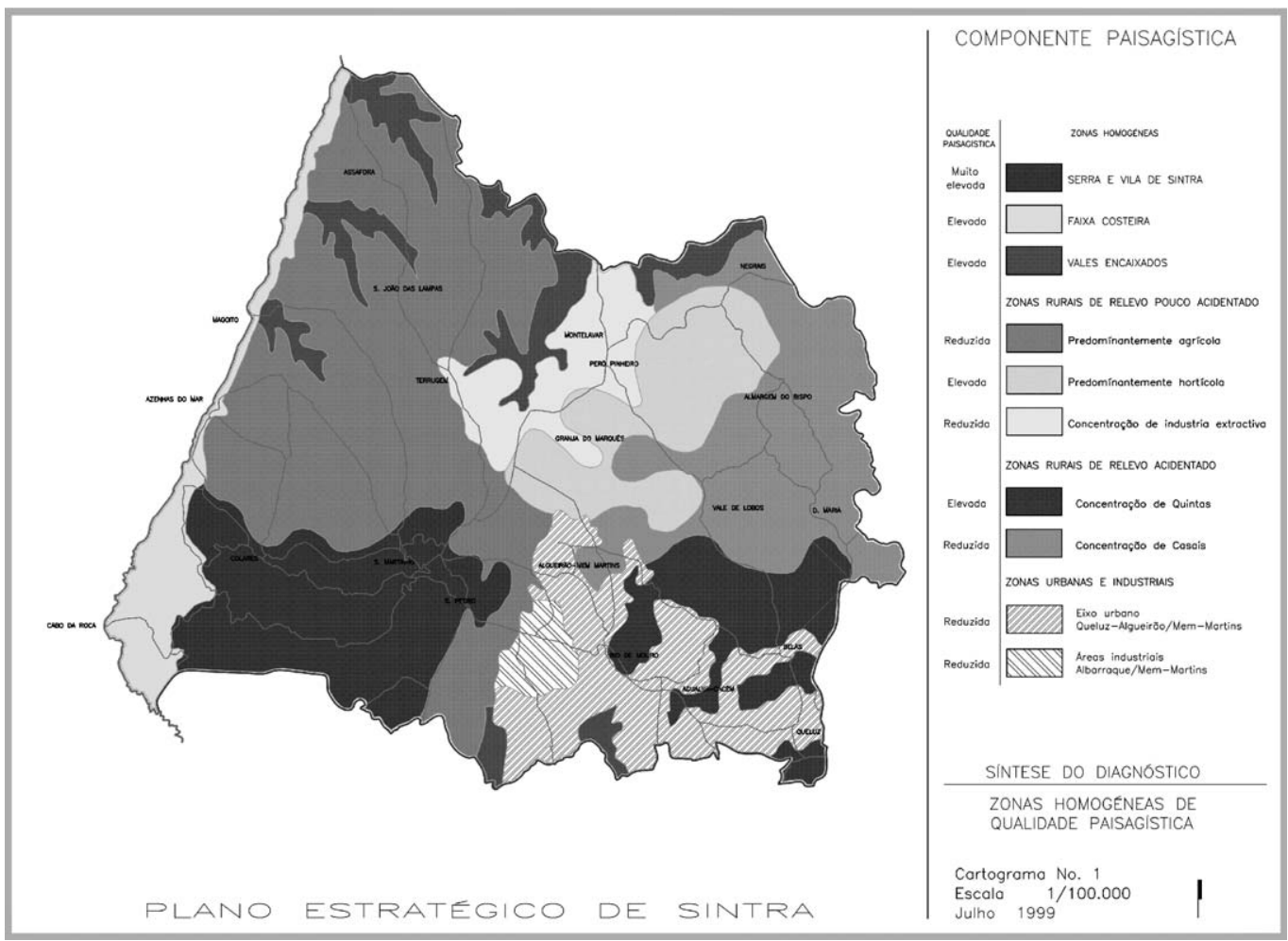

Fig. 3. Landscape assessment in Sintra municipality.

- To contain the megalopolis. A continuous system of non-developed areas should be fostered on the municipal and inter-municipal scale, along its main urban and industrial corridors.

Framed by these goals and considering the context of the strategic plan, the planning team considered planning of a greenway composed of areas of outstanding landscape (Fig. 4) an applicable planning concept. This system was designed based upon the spatial patterns of valuable resources, being therefore areas of high concentration and co-occurrence of valuable resources. The system also considered the expansion of legally protected areas as well as the rehabilitation of derelict and degraded landscapes.

Those areas protected by existing planning tools, such as the National Ecological Reserve and the National Agriculture Reserve, constitute an important system that should be complemented by other strategies. This aspect is particularly significant within the perimeter of suitable zones for development where the appli- cation of the National Ecological Reserve and the National Agriculture Reserve is not as well defined as in rural areas. The same applies outside the area classified as World Heritage by UNESCO. The goal is to expand the area of exceptional quality to the entire municipality.

The greenway network for Sintra municipality should be understood as an infrastructure that contributes as any other - water, sewerage, transportation and energy - to achieve sustainable development and quality of life for the population. Such an infrastructure will enable, safeguard and perpetuate the most significant natural landscape resources as well as those resulting from a millennium of settlement of this territory.

In the context of the multidisciplinary planning team collaborating on the strategic plan, the concept of greenway was an efficient means of conveying the need for resource protection and the opportunities it would provide in terms of municipal development. It differentiates itself from the RAN (National Agriculture Reserve) and the REN (National Ecological Re- 


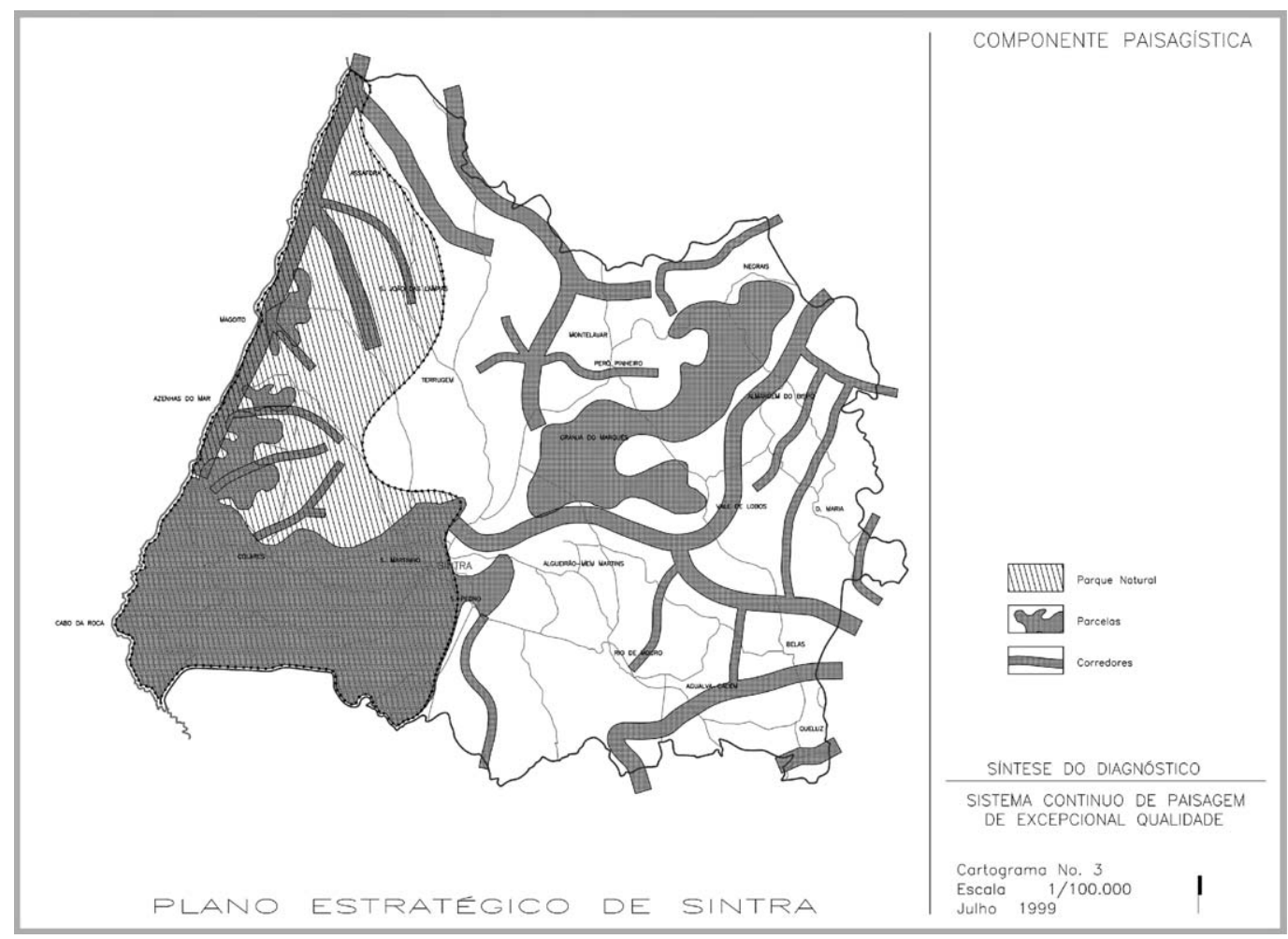

Fig. 4. Sintra greenway: a network of Outstanding Landscape Quality.

serve) thereby overcoming restrictive aspects and emphasizing the opportunities that arise from such a network of Outstanding Quality Landscape.

\subsection{The Greenway of Vila-Franca-de-Xira Hills}

\subsubsection{General context and objectives}

The Greenway of Vila-Franca-de-Xira Hills was proposed to the political authorities of Vila-Franca-deXira, a municipality situated along the Tagus River and included in the Lisbon Metropolitan Area (Ribeiro et al., 2000). The roots of the Tagus Valley region are linked to a cultural landscape structured in large estates which include intensive agriculture and cattle breeding. These activities also support the bullfighting tradition which is still rooted in the local population. The city's urban expansion needs are limited by the river and flood plain towards east and south and by very steep limestone hills towards the north. The greenway was presented as a strategy for the population to once again use the nearby limestone hills and to overcome the current view that they are a constraint on city development. The landscape architecture office TOPIARIS developed the plan.

\subsubsection{Landscape assessment and identification of valuable resources}

The assessment of the landscape and the identification of valuable resources - natural, historic/cultural, and opportunities for recreation - became the foundation for the greenway plan and design. A parametric approach for landscape analysis was first developed including geology, physiography, natural drainage, vegetation, streets and trails network, and sites of historic/cultural interest. Landscape assessment methodology was used to identify the most valuable resources.

The Hills are constituted of limestone formations which emerge almost 100 meters above the Tagus flood plain. Very steep slopes - mainly above $30 \%$ - covered by natural Mediterranean shrub vegetation, characterize the hillsides. These geomorphologic units and the contrast they create with the surrounding plains make 
them a remarkable feature in terms of landscape quality. This is corroborated by the existing belvederes as well as ancient evidence of human settlement. The cultural resources include vestiges of pre-historic, Roman and Muslim occupations as well as a medieval shrine and burial ground. The shrine is still a significant religious place for the city as well as for a larger public related to the bullfighting tradition. Bullfighters from Portugal and Spain use it for worship, asking for divine protection before entering the arena.

The Hills' visual resources together with their microclimatic conditions - south facing - and their proximity to the city and urban recreation facilities, make them an exceptional opportunity for expanding the population's leisure activities.

\subsubsection{Greenway design}

Based upon the co-occurrence of these resources, a greenway network was delineated (Fig. 5). The identification of protection gaps and conflicts with approved plans for residential developments were the bases for the design and implementation strategy. Three lines of action were therefore proposed and are currently being carried out:

- Protect areas with significant natural and ecological value not yet under the protection of existing planning tools.

- Develop guidelines to be followed by approved plans for residential development, in order to warrant the existence of a continuous network of green spaces and trails.

- Identify areas which landscape design proposals can target in order to implement and construct outdoor spaces and trails. These actions include the rehabilitation of historic places and the construction of pedestrian trails and outdoor recreation facilities.

The greenway will include a linear area of about $1.5 \mathrm{~km}^{2}$ as well as around $10 \mathrm{~km}$ of trails connecting areas of natural interest, and historical/cultural value-a medieval shrine, Muslim sites, and an outstanding panoramic looking over the Tagus river. It also provides a connection with educational and recreational facilities already existing in the city-schools, camping ground, public park and public swimming pools. The creation of such a greenway will help to improve environmental and visual quality, the population's identity, as well as recreation, education and tourism attraction. The acceptance of this greenway is further corroborated by its analysis and its diffusion in the local media.

\subsection{The Urban Greenway of Tomar}

\subsubsection{General context and objectives}

The proposal of an Urban Greenway for Tomar was developed as a strategic project for downtown environmental and urban rehabilitation under the coordination of the planning office of CEDRU (Gaspar et al., 2001). Tomar is an important municipal urban center with a population of 18,000 inhabitants, located in the central region of Portugal. Its importance and quality in terms of history and landscape makes it an important reference and tourist destination. The River Nabão, running north to south, has throughout history played a significant role as an infrastructure for communication, energy source and recreation. Tomar's urban fabric shows evidence of the Roman and Templar Religious Order which, after the 14th century, became the Christ Order which fostered the discoveries.

With the greenway proposal as the project's central concept, it made possible to carry out a set of rehabilitative actions under the Polis program, a governmental program for allocating funds for urban and environmental rehabilitation of cities (Polis Program, 2002).

\subsubsection{Landscape assessment and identification of valuable resources}

The corridor along the River Nabão is endowed with a high quality landscape resulting from the presence of significant natural and historic/cultural resources, namely:

- Development of remarkable vegetation along the riverbanks and flood plain.

- Fertile soils and vegetable garden areas along the riverbanks and large water body provided by the permanent flow of the river.

- Significant industrial heritage associated with hydraulic facilities, religious buildings and bridges.

- Historic urban fabric and buildings along the river.

\subsubsection{Greenway design}

The design of the greenway includes an area of about $0.15 \mathrm{~km}^{2}$ along $4 \mathrm{~km}$ of river (Fig. 6), providing a diverse range of activities. A pedestrian $6.0 \mathrm{~km}$ network 

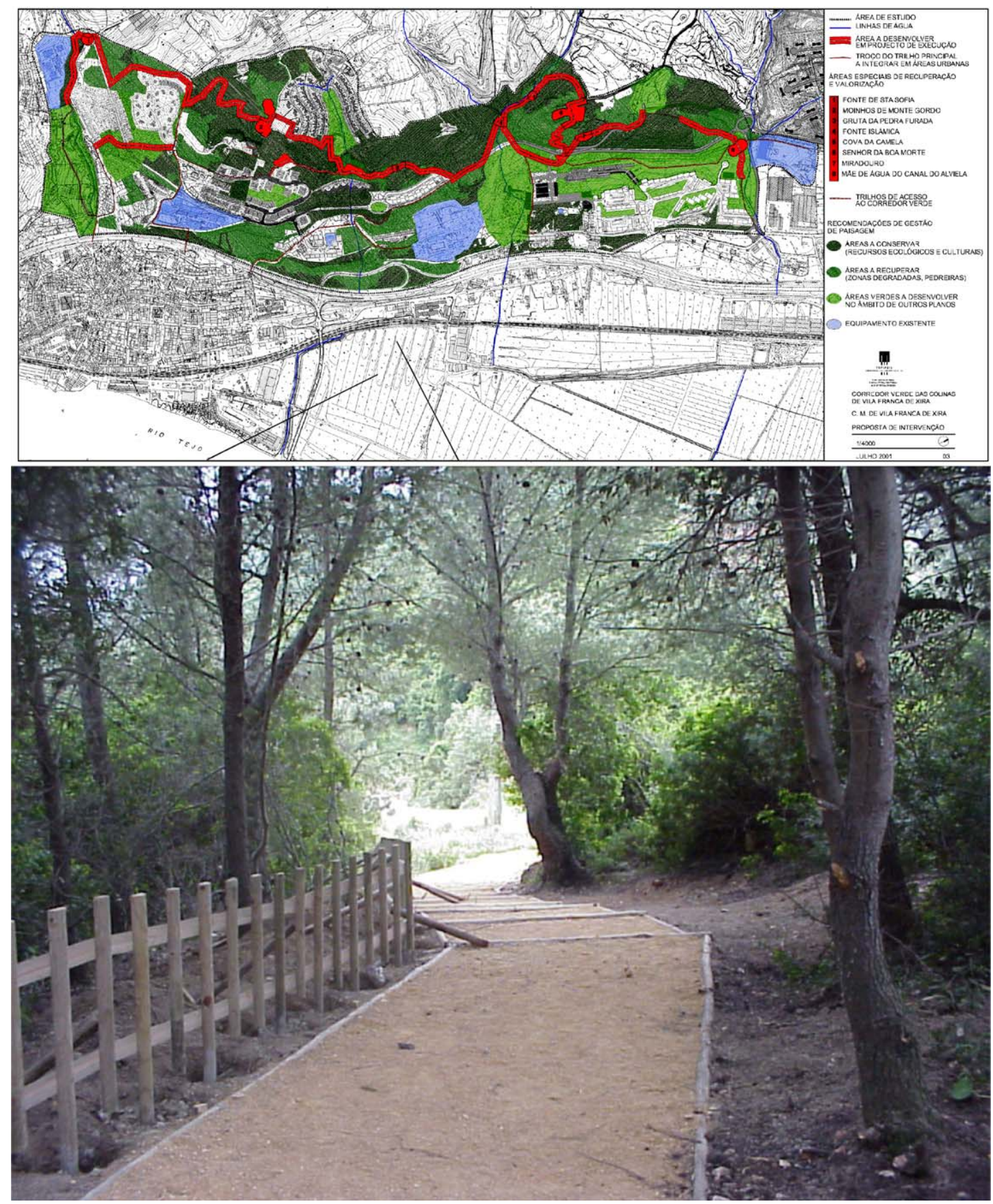

Fig. 5. Urban Greenway of Greenway of Vila-Franca-de-Xira's Hills. General plan (upper); constructed trail in the first phase (bottom). 


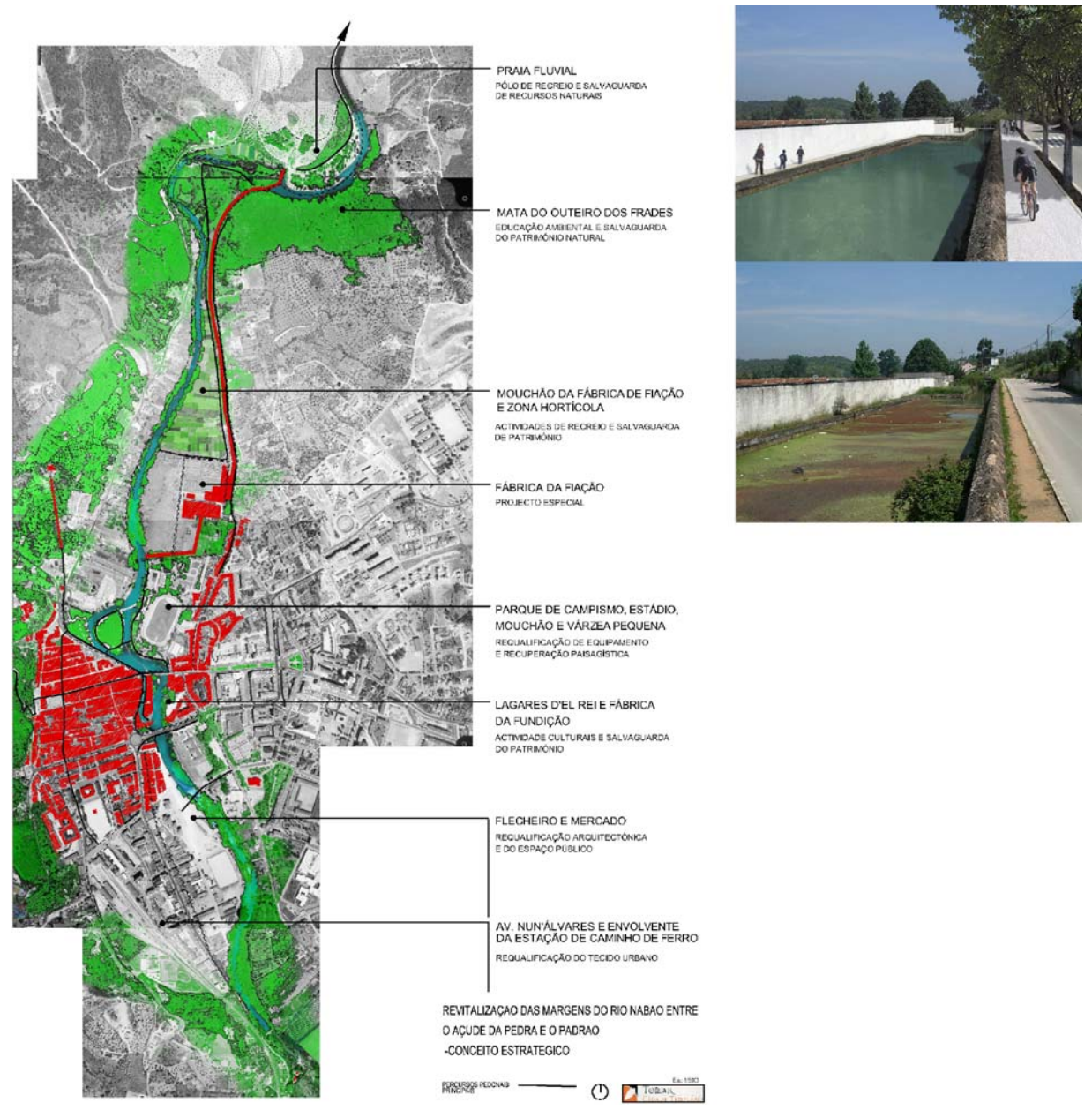

Fig. 6. Urban Greenway of Tomar. General concept (left); existing condition (bottom); visual simulation of proposal (upper).

of trails provides the access and use of the rich and diverse heritage, throughout old historic districts and luxurious vegetation along the riverbanks. This network itself becomes an infrastructure for recreation and tourism, whose value is increased and complemented by other activities related to the river, such as fishing, water sports, river beach as well as sporting areas, parks, gardens and fair grounds.

This project was intended to go beyond the creation of an infrastructure for recreation and tourism by becoming a central planning tool for city growth towards sustainable development which would protect valuable resources and simultaneously provides new economic opportunities related to tourism, recreation and educa- tion. The Polis program has recognized these opportunities, by allocating funds to implement the project.

\subsection{The Greenway of Alpiarça Canal}

\subsubsection{General context and objectives}

The Greenway of Alpiarça Canal represents a transmunicipal project, the initiative of two municipalities Alpiarça and Almeirim - with the support of the Association of the Tagus Valley Municipalities and coordination of the CEDRU planning office. This association is responsible for allocating governmental funds for environment improvement and establishing links between central and local political powers. The aim was 
to improve the environmental and landscape quality of a drainage canal built about 200 years ago (Simões et al., 2000). Currently the canal's low water quality levels are related to sewage discharges and non-point pollution sources, which also provide determines specific conditions for the development of vegetation with low ecological value. The canal is about $30 \mathrm{~km}$ long and runs along the agriculture areas of the fertile Tagus flood plain and links three villages and several places significant for nature conservation, recreation and culture.

\subsubsection{Landscape assessment and identification of valuable resources}

The Tagus River Valley has been settled for millennia, with a network of canals built for communication, drainage and irrigation of farmlands. The importance of this cultural landscape is corroborated by its recent application (2001) for classification as a UNESCO World Heritage Landscape.

A study of the area also followed a systematic assessment of the landscape which identified the main resources along the canal. The Alpiarça Canal owes its natural value to the hydrological and ecological functions it performs. Along its banks areas of natural vegetation and habitats exist related to wetland areas. As part of the valley's cultural landscape the canal also crosses areas of significant cultural value such as farmlands, related networks of roads and lanes and 19th century estates, which provide high quality views.

The Alpiarça Canal has great potential as a recreational resource since it allows for the practice of different activities along its banks, namely fishing, rowing, horse back riding, biking, jogging and walking. At the same time it runs very close to already existing sports and recreational facilities, due to its proximity to the city centers of both Almeirim and Alpiarça. All of these elements are currently seen as resources for tourism. Public and private initiatives are promoting local tourism based on traditional estates or thematic itineraries such as wine routes which allow for the visit of vineyards and wineries.

\subsubsection{Greenway design}

The proposed greenway was delineated along its banks (Fig. 7), and suggested the development of the following facilities:
- Trails for pedestrian and biking circulation.

- Platforms enabling closer contact and access to the water for fishing and rowing.

- Areas for picnicking.

- Parking lots near access points for pedestrians.

The strategy also included actions to rehabilitate natural vegetation as well as to establish newly-planted areas, using species indigenous to the natural ecosystems. The proposed greenway would make it possible to link already existing recreational, cultural and tourism sites along the Canal with each other, as well to the two cities' urban centers.

The local municipal and regional planning authorities accepted the proposed greenway strategy. It is currently being adopted by other municipalities - members of the Association of Municipalities of the Tagus Valley - to rehabilitate other canals and implement recreational trails across the valley and along the riverbanks.

\subsection{The Urban Greenway of Alenquer River}

\subsubsection{General context and objectives}

The Urban River Greenway of Alenquer was a means of improving and rehabilitating the banks of the Alenquer River which traverses the village. Such a project was developed upon the suggestion of regional planning authorities after analysis of the greenway proposed for Tomar. The village of Alenquer is the center of a municipality $36 \mathrm{~km}$ north of the Lisbon Metropoli$\tan$ Area. The river - the source of huge floods - crosses the downtown area of this historical village. An analysis of the village and river corridor's opportunities and the hydraulic proposal to canal the river, guided a strategy to implement a $5 \mathrm{~km}$ long Urban Greenway (Barroso et al., 2001). This strategy was able to reconcile the objectives of the National Authority for Water Resources, local politicians and planning authorities for the Tagus Valley region. The plan was developed under the coordination of the planning office of CEDRU.

\subsubsection{Landscape assessment and identification of valuable resources}

The river corridor possesses diverse characteristics such as both rural and urban areas located in the flood plain. The quality of the landscape is defined by a deep and narrow valley with steep banks on which the historic village settled and a sinuous river. 
Valorizaçāo paisagistica da Vala de Alpiarça
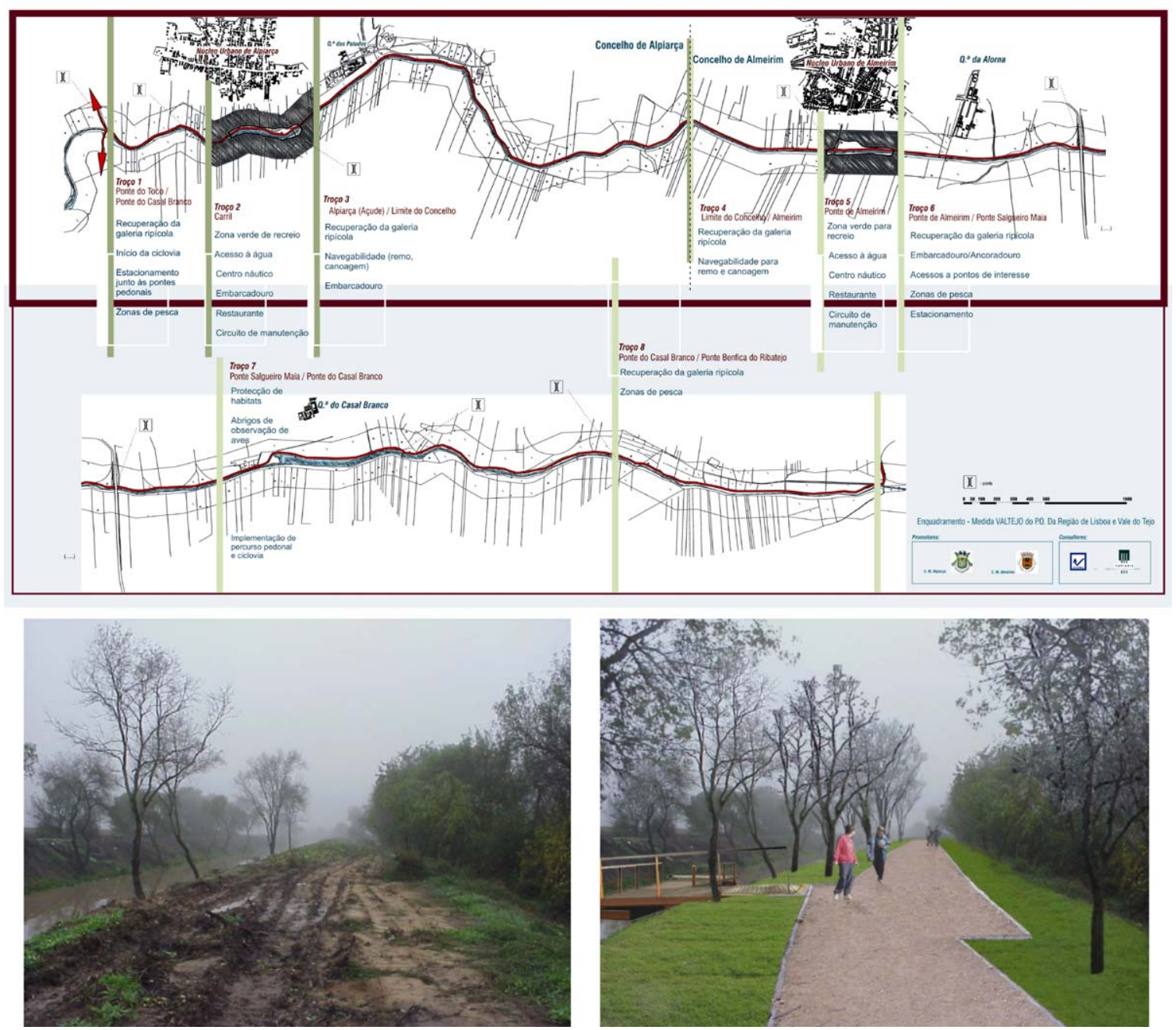

Fig. 7. Greenway of Alpiarça's Canal. General plan (upper); existing condition (bottom left); proposal (bottom right).

The landscape assessment identified the main resources along the river corridor and supported the delineation of six homogenous areas. A set of actions was defined for each area in order to guide landscape design projects which, as a whole will make it possible to improve the riverbanks and adjoining public spaces.

\subsubsection{Greenway design}

The proposed design for the greenway was delineated upon the existing natural and cultural/historical resources. The winding course of the river together with the diversity of the landscape, historic buildings and public spaces constitute an opportunity to create a greenway that will function as a unifying element through the village (Fig. 6).

The proposed greenway therefore included rehabilitating historic buildings and improving neighboring public spaces, creating a new sports' zone, improving a traditional fairground as well as generally improving the streets and public spaces along riverbank. (Fig. 8). The connection with the campground upstream and to the rural areas downstream expanded the range of this greenway as an ecological corridor and a bike and pedestrian trail. The proposal had to be reconciled 


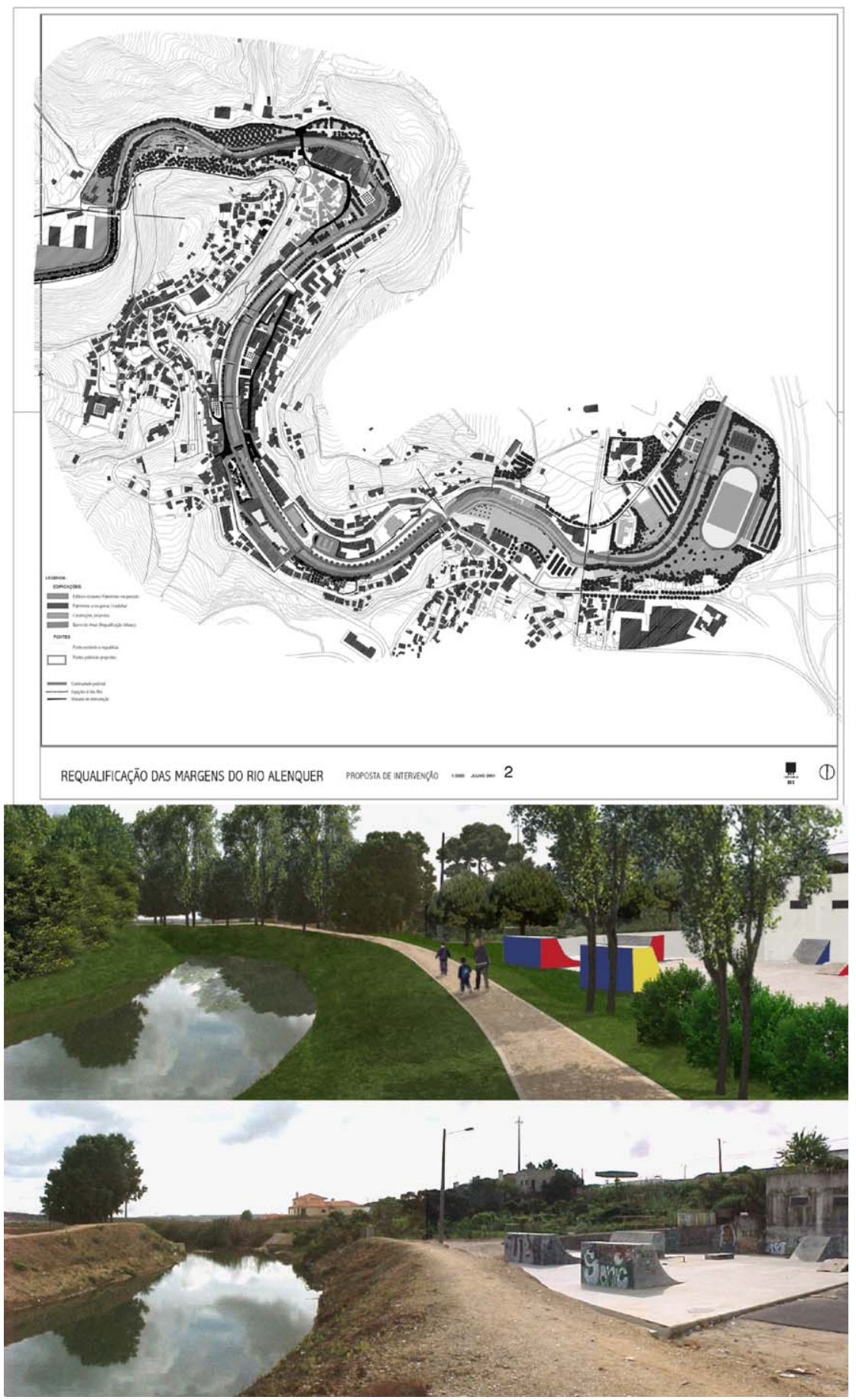

Fig. 8. Urban Greenway of Alenquer river. General plan (upper); existing condition (middle); proposal (bottom). 
with previously approved projects such as the hydraulic projects for the river. Once again, the greenway concept revealed itself as a planning and design tool capable of achieving consensus among different professions dealing with planning and design.

\section{Conclusions}

This section aims to compare the five greenways described in terms of their characteristics and the context in which they were developed. The objective is to evaluate the effectiveness of the greenway concept as a planning and design tool when applied to the Portuguese landscape and planning context. Table 2 synthesizes the main characteristics and outreaches of each of the five examples.

The comparative analysis of the greenways case studies highlighted four main issues related to the use of the greenway concept as a design and planning tool in Portugal. The first deals with the applicability of landscape assessment methods for the identification of valuable resources in the landscape. The second refers to the importance of the spatial patterns revealed by these assessment methods in the design of greenways. The third concerns greenway planning and design as a strategy which relies both upon rational parametric assessment methods as well as creativity. Finally the geographic context as well as the political and planning context in which these examples occur, proves the applicability of the greenway concept in Portugal. In the following paragraphs these four aspects will be discussed in more detail.

In all five case studies, the method implies there is an awareness of valuable resources existing in the landscape which determines its quality and which provide opportunities for development and leisure. The use of parametric landscape assessment methods enabled the identification of these resources in a more reliable and objective way. It made it possible to convey the existence of these resources to different planning and design team members.

The delineation of a greenway as a strategy to conserve and improve landscape quality, either within a planning or design approach, was achieved in the five case studies through processes that include both the analysis of resources distribution patterns as well as design creativity. Greenway planning and design can be seen as a strategy that is supported by rational and objective approaches of landscape planning, recognizing the importance of creativity and human decision and hence a concept that attempts to address post-modern criticism.

Parametric methodologies used to identify valuable resource patterns for greenway planning and design have been tested in different contexts as shown by Lewis (1964) in Wisconsin State or by Dawson (1995) in Georgia, among others. In Portugal, these methodologies were also useful both for project development, as well as to improve communication with other team members with backgrounds other than landscape architecture or ecology. This was most evident in the Sintra Greenway project due to its regional scale. It was part of a strategic plan developed to aid revision of the existing municipal land use plan and therefore included a quite large and diversified team.

The five examples were planned and drawn considering the distributions patterns of the valuable resources on the land, therefore considering the principles of rational planning. However, the patterns which the parametric approaches revealed were used in different ways. All five examples were based on linear features on the land such as ridgelines on VilaFranca-de-Xira's Hill's stream and drainage networks in Tomar, Alenquer and Alpiarça, and both features in the Sintra municipality. However, diverse strategies were developed in response to these linear patterns. Ahern's classification of protective, defensive, offensive and opportunistic (Ahern, 1995) shows this diversity.

The Sintra Greenway of Outstanding Landscape Quality was very much concerned with protecting existing resources which determine the existing quality and character. Its goal was to project that existing quality in some clusters to newly developed areas through a new system of parks, gardens and public spaces often in a non-supportive landscape matrix. The strategy is therefore both protective and offensive.

The strategy applied to the Vila-Franca-de-Xira Hills is both a protective and defensive strategy in response to the resources identified. Some of these resources were protected by avoiding development, whereas others were safeguarded within new areas of development.

The Tomar Greenway along the Nabão River took a complex protective, offensive and opportunistic 
Table 2

Comparative analysis of the five greenways case studies

\begin{tabular}{|c|c|c|c|c|c|c|c|}
\hline & Significant resources & Land use & Area $\left(\mathrm{km}^{2}\right)$ & $\begin{array}{l}\text { Extension of } \\
\text { trails }(\mathrm{km})\end{array}$ & Provided activities & $\begin{array}{l}\text { Accessibility and urban } \\
\text { connections }\end{array}$ & $\begin{array}{l}\text { Outreach beyond } \\
\text { landscape architecture }\end{array}$ \\
\hline \multirow[t]{5}{*}{$\begin{array}{l}\text { Sintra Greenway of } \\
\text { Outstanding } \\
\text { Landscape Quality }\end{array}$} & $\begin{array}{l}\text { Areas of high landscape } \\
\text { quality }\end{array}$ & Rural landscape & $\begin{array}{l}400 \\
\text { (municipality } \\
\text { area) }\end{array}$ & $\begin{array}{l}\text { Roads and rural } \\
\text { trails network }\end{array}$ & Driving & Sintra village & $\begin{array}{l}\text { Accepted concept by a } \\
\text { multidisciplinary team, } \\
\text { coordinated by } \\
\text { geographers }\end{array}$ \\
\hline & World heritage landscape & Urban areas & & & Walking & Coastal villages & \\
\hline & 500 historic sites & $\begin{array}{l}\text { Recreation opportunities } \\
\text { (hills and coast) }\end{array}$ & & & Picnicking & Rural villages & \\
\hline & $\begin{array}{l}\text { Areas of ecological } \\
\text { significance }\end{array}$ & & & & Beach & Residential areas & \\
\hline & & & & & Heritage tourism & & \\
\hline \multirow{3}{*}{$\begin{array}{l}\text { Greenway of Vila- } \\
\text { Franca-de-Xira's } \\
\text { Hills }\end{array}$} & Limestone hills & Steep shrub land & 1.5 & 10 & Walking & $\begin{array}{l}\text { Through out developed } \\
\text { areas }\end{array}$ & Municipal authorities \\
\hline & Mediterranean shrub land & Abandoned quarries & & & Riding & $\begin{array}{l}\text { To parks, camping } \\
\text { grounds, schools }\end{array}$ & $\begin{array}{l}\text { Accepted concept within } \\
\text { a multidisciplinary team }\end{array}$ \\
\hline & $\begin{array}{l}\text { River corridors } \\
\text { Pre-historic, Muslin, } \\
\text { Roman, medieval sites } \\
\text { Visual resources }\end{array}$ & Developable land & & & $\begin{array}{l}\text { Landscape interpretation } \\
\text { Worship areas }\end{array}$ & & \\
\hline \multirow[t]{4}{*}{$\begin{array}{r}\text { Tomar Urban } \\
\text { Greenway }\end{array}$} & Downtown area & Urban area & 0.15 & 4 & Walking & $\begin{array}{l}\text { Pedestrian areas through } \\
\text { downtowns }\end{array}$ & $\begin{array}{l}\text { National Plan for cities } \\
\text { improvement (Polis } \\
\text { program) }\end{array}$ \\
\hline & Historic district & Green spaces & & & Biking & Sporting area & Municipal authorities \\
\hline & River banks & $\begin{array}{l}\text { Market, sport fields, } \\
\text { associations }\end{array}$ & & & Jogging & Fair grounds & $\begin{array}{l}\text { Multidisciplinary } \\
\text { planning team }\end{array}$ \\
\hline & $\begin{array}{l}\text { Heritage (medieval and } \\
\text { industrial sites) } \\
\text { Natural vegetation } \\
\text { Visual resources }\end{array}$ & Commercial & & & Economic opportunities & & \\
\hline \multirow[t]{5}{*}{$\begin{array}{l}\text { Greenway of } \\
\text { Alpiarça Drainage } \\
\text { Canal }\end{array}$} & Historical canal & $\begin{array}{l}\text { River bank natural } \\
\text { vegetation }\end{array}$ & 1.0 & 30 & Walking & $\begin{array}{l}\text { Enable access to } 2 \text { down } \\
\text { towns }\end{array}$ & $\begin{array}{l}\text { Accepted by regional } \\
\text { authorities for funds } \\
\text { allocation }\end{array}$ \\
\hline & Tagus floodplain & Water & & & Riding & $\begin{array}{l}\text { Access to estates, and } \\
\text { museum }\end{array}$ & $\begin{array}{l}\text { Accepted planning } \\
\text { strategy by a } \\
\text { multidisciplinary team }\end{array}$ \\
\hline & Natural vegetation & Agriculture & & & Biking & & \\
\hline & Water resources & & & & Fishing & & \\
\hline & $\begin{array}{l}\text { Estates, museum } \\
\text { Sporting areas }\end{array}$ & & & & Rowing & & \\
\hline \multirow[t]{4}{*}{$\begin{array}{l}\text { Urban Alenquer } \\
\text { Greenway }\end{array}$} & Downtown area & Urban area & 1.0 & 5 & Walking & $\begin{array}{l}\text { Trails and pedestrian } \\
\text { areas through } \\
\text { downtowns }\end{array}$ & $\begin{array}{l}\text { Water Management } \\
\text { National Authority }\end{array}$ \\
\hline & River banks & Green spaces & & & Biking & Sporting area & $\begin{array}{l}\text { Tagus Valley Region } \\
\text { Planning Authorities }\end{array}$ \\
\hline & $\begin{array}{l}\text { Heritage areas (medieval } \\
\text { and industrial) }\end{array}$ & $\begin{array}{l}\text { Market, sport fields, } \\
\text { associations }\end{array}$ & & & Jogging & & Municipal authorities \\
\hline & Visual resources & Commercial use & & & Economic opportunities & & $\begin{array}{l}\text { Accepted concept by a } \\
\text { multidisciplinary team }\end{array}$ \\
\hline
\end{tabular}


strategy. Patches and corridors of special natural and ecological value were protected. Meanwhile, in those areas with a non-supportive landscape but with opportunities for new development, either new corridors and green areas were proposed, or links to existing areas of great cultural and natural value, to increase already existing opportunities for tourism and recreation.

In the case of the Alpiarça drainage canal, a corridor of derelict land along a major water resource, the aim was to defend the existing water line by creating a buffer zone with maintained natural vegetation and recreation facilities. This strategy should be considered as mainly defensive.

The aim of the Alenquer Greenway the strategy was to link patches and sites along the river of natural and cultural value with a new network of high quality public spaces. This network was designed to take advantage of the fact that hydraulic works were to be carried out along the banks of the river. It used the same funds and made possible a new supportive landscape for the greenway. This strategy can therefore be described as mainly opportunistic.

Finally, these five examples were successful in convincing and conveying the main objectives to different political and official planning agencies involved. This may be related in part to the use of landscape parametric methods together with the greenway concept thus supporting and reconciling different planning objectives such as landscape conservation, development and recreation.

The Tomar Greenway is worth mentioning here in first place, since its strategies to rehabilitate the landscape and improve the Nabão river corridor aided Tomar in successfully applying to the Polis program, a government program for allocating of public funds to improve the environment and landscape in Portuguese cities. The Alenquer Greenway should be mention as the next, in importance since the current Mayor had proposed it in his agenda and was therefore motivated by political and electoral objectives. This proposal also affected some of the area's public works projects hydraulic correction of the river, and traffic circulation - and improved the quality of public spaces. The Greenway of the Alpiarça Canal is an example of a project carried out on a regional planning scale and was developed as a landscape design project. Since it was a trans-municipal project it was able to secure funds from two municipalities. Our final example - the
Greenway of the Vila-Franca-de-Xira Hills - became an important means of overcoming negative opinion regarding the hills which politicians and developers had considered restrictive. The greenway proposal showed politicians and developers that the hills were extremely important to the city's cultural identity and landscape character and provided both unavoidable opportunities in the areas of recreation, tourism and environmental improvement, and added value to nearby areas of development.

Our analysis of these five case studies shows the significance of greenways as a planning and design strategy that coincides with the current objectives of political and planning authorities on the municipal level. It also proves that it is possible to reconcile political objectives and urban development while safeguarding landscape quality and creating new opportunities for public recreation and education.

As concerns political power, these examples demonstrate that by implementing greenways it is not only possible to improve landscape quality but also to create new leisure opportunities. Politicians believe this affects peoples' quality of life and will therefore bring back their support.

Official planning agencies also embraced these greenways cases since these projects enabled the allocation of more funds by reconciling different fields and planning objectives. Successful results and rates of execution of different planning objectives have in some ways assured that planning agencies will allocate future funds to similar projects thus strengthening the role of greenways in Portugal.

The greenway concept becomes more significant if we consider the existing planning context in Portugal. Although there is a tradition of landscape architecture and ecological planning, the official legal tools and planning system are very recent. The REN (National Ecological Reserve) and the RAN (National Agricultural Reserve) are good examples of this since they were only approved in 1982 and 1983. Furthermore, the means to achieve efficient planning involving diverse agents as well as public participation are not yet very effective. Actually, state and regional planning agencies often tend to be more enthusiastic about public works related to infrastructures, which are more closely related to basic needs.

The five examples made possible the expansion of greenways in the Tagus Valley region and increased op- 
portunities for landscape architecture design projects since they will require further development in the projects' design and construction phases. Hence, this has expanded opportunities for landscape architects.

All of these examples have shown to a certain degree the acceptance of the greenway concept as a planning and design tool beyond landscape architecture having been embraced by other professions dealing with planning and design, as well as by politicians and governmental planning authorities. Therefore, the greenway concept has become a tool not only for protecting resources and connecting places but also a mean of improving communication between different professions dealing with planning and design, thus contributing to a better global landscape.

\section{Acknowledgements}

The authors want to express their gratitude to the CEDRU planning office (Centro de Estudos de Desenvolvimento Regional e Urbano), mainly to Prof. Jorge Gaspar, Prof. José Manuel Simões and the geographer Sérgio Barroso, for the opportunity to explore the greenway concept in real planning studies within multidisciplinary teams. Special thanks also to the TOPIARIS design team, mainly to Catarina Viana, Rita Salgado and Samuel Alcobia who together with the authors, enthusiastically developed the proposals for the five greenways.

\section{References}

Ahern, J., 1995. Greenway as a planning strategy. Landsc. Urban Planning 33, 131-155.

Andresen, T., 2001. Francisco Caldeira Cabral. Landscape Design Trust, Surrey, UK, 213 pp.

Barroso, S., (coord.), 2001. Projecto de requalificação urbana e valorização ambiental das margens do Rio Alenquer. CEDRU, Lisboa, 72 pp.

Cabral, F.C., 1980. O Continuum Naturale e a Conservação da Natureza. Conservação da Natureza. Serviço de Estudos do Ambiente, Lisbon.

Churchill, H., 1983. Henry Wright: 1878-1936. In: Krueckeberg, D.A. (Ed.), The American Planner: Biographies and Recollections. Methuen, New York, pp. 208-224.

Dawson, K., 1995. A Comprehensive conservation strategy for Georgia's greenways. Landsc. Urban Planning 33, 27-43.
De Gröer, E., 1948. Plano Director de Urbanização de Lisboa. Câmara Municipal de Lisboa, Lisbon.

Fabos, J.Gy., Caswell, S., 1977. Composite Landscape Assessment: Assessment Procedures for Special Resources, Hazards and Development Suitability; Part II, Metropolitan Landscape Planning Model (METLAND). Research Bulletin no. 637, Agricultural Experiment Station, University of Massachusetts, MA.

Fabos, J.Gy., 1991. From Park to Greenways into the 21st Century. In: Proceedings from Selected Educational Sessions, ASLA Annual Meeting, Kansas City, Missouri.

Fabos, J.Gy., 1995. The greenway movement, uses and potentialities of greenways. In: Fabos, J.Gy., Ahern, J. (Eds.), Greenways: The beginning of an international movement. Elsevier, Amsterdam, pp. $1-13$.

Gaspar, J., et al., 2001. Projecto de Revitalização das margens do Rio Nabão entre o Açude de Pedra e o Padrão. CEDRU, Lisboa.

Geddes, P., 1996. In: LeGates, R.T., Stout, F. (Eds.), City Survey for Town Planning Purposes of Municipalities and Government. The City Reader, New York, Routledge, pp. 360-366.

Lewis, P., 1964. Quality corridors for wisconsin. Landsc. Architect. January, 101-107.

Lôbo, M.S., 1995. Planos de Urbanização: a Época de Duarte Pacheco. DGOTDU/FAUP, Porto, 305 pp.

Lyle, J.T., 1985. Design for Human Ecosystems. Van Nostrand Reynolds Company, New York, p. 279.

Machado, J.R., et al., 1995. Metropolitan Landscape Planning: a Greenway Vision for the Lisbon Metropolitan Area (AML). Special Issue Landscape, 95-3.

Marques, A.O., 1981. História de Portugal. Palas Editores, Lisbon.

McHarg, I., 1969. Design With Nature. Natural History Press, New York, 197 pp.

ProgramaPolis, 2002. Polis em Números. Ministério do Ambiente e Ordenamento do Território (Ministery for Environment and Landscape Planning), Lisbon.

Ribeiro, L., et al., 2000. Corredor Verde das Colinas de Vila-Francade-Xira. TOPIARIS, Lisboa.

Ribeiro, L.F., 1998. The Cultural Landscape and the Uniqueness of Place: A Greenway Heritage Network for Landscape Conservation of Lisbon Metropolitan Area. Ph.D. Dissertation in Regional Planning. University of Massachusetts, Amherst, MA, 1998, 396 pp.

Simões, J.M. (coord.), 2000. Valorização ambiental lúdica e turistica da Vala Real de Alpiarça. CEDRU, Lisboa, 53 pp.

Simões, J.M., et al., 1995. Plano Estratégico de Sintra (Strategic Plan for Sintra Municipality), vol. 1. CEDRU, Lisboa, $171 \mathrm{pp}$.

Telles, G.R., et al., 1997. Plano Verde de Lisboa. Ed. Colibri, Lisboa, 197 pp.

Telles, G.R., 1992. A Paisagem Global do Concelho de Lisboa. AGROS 2, 5-9.

Luis Paulo Faria Ribeiro is a faculty member in Landscape Architecture degree at the High Institute of Agronomy/Lisbon Technical University, where he has been Department Head and Landscape Architecture Degree Director, and presently coordinating research work on cultural landscapes management and conservation. He is also partner in the landscape architecture office of TOPIARIS, de- 
veloping landscape planning, design and management projects. He got the $\mathrm{PhD}$ in Regional Planning at the Department of Landscape Architecture and Regional Planning, UMASS Amherst.

Maria Teresa Barao Dias is a partner of the Landscape Architecture office of TOPIARIS, as Project Director, coordinating projects on the areas of Landscape Planning, Design and Management. She is a former consultant in landscape design and management of the Portuguese Agency for Energy. She got her degree on landscape architecture at the High Institute of Agronomy/Lisbon Technical University. 